\title{
QFD FOR SERVICES PROVIDED BY GRAIN PRE-PROCESSING COMPLEXES IN THE LATVIAN MARKET
}

Inara Jurgena ${ }^{1}$,Dr.oec. and Aina Muska ${ }^{2}$,Dr.oec., Roberts Aispurs ${ }^{3}$, Mg.oec.

1,2 Faculty of Economics and Social Development, Latvia University of Life Sciences and Technologies, ${ }^{3}$ SIA "Skonto Plan Ltd"

\begin{abstract}
An analysis of the grain industry in Latvia reveals that crop yields and the cropped area tended to increase in recent years. The most popular crops grown were wheat, barley and rapeseed.

The research aim is to examine the characteristics of services provided by a grain pre-processing complex in the Latvian market based on the example of Amazone Ltd. The research compared the requirements of customers against the characteristics of grain pre-processing services by using a quality function deployment matrix, and direct competitors were compared by means of the point method.

Grain pre-processing is a very specific industry; for this reason, experience and a workforce of high quality play an essential role in competing with market leaders.
\end{abstract}

Key words: grain farming, grain pre-processing complex, Quality Function Deployment JEL code: M11, Q11, Q16

\section{Introduction}

Crop farming is the key agricultural industry that produces food, feed and commodities for other industries. To perform an in-depth examination, it is necessary to identify and analyse trends in the production of crops supplied to grain pre-processing complexes. In Latvia, any kind of grain is preprocessed (wheat, barley, oats, rye etc.), industrial crops (rapeseed) and pulses (faba beans and common peas).

In human diets, an increasing role is plaid by grain in particular. In developed countries, the diets are reviewed, with more focus being placed on all kinds of grain. Nutrition specialists believe that in human diets grain products have to make up approximately $40 \%$ of the total food consumed.

Grain is an important source of nutrition, and grain farming has always been one of the national priorities in Latvia. To promote the development of grain farming, Latvia has to perform several strategic tasks:

- national independence in relation to grain production, which ensures the development of other agricultural industries and secure food supply;

- the rural population is employed and earn guaranteed incomes;

- the rural environment is maintained in good condition.

The research aim is to examine the characteristics of services provided by a grain preprocessing complex in the Latvian market based on the example of Amazone Ltd. Specific research tasks:

1) To characterise the situation in and projections for the grain industry in Latvia.

2) To examine the voice of the consumer for grain pre-processing services.

3) To construct a QFD matrix for potential grain pre-processing services provided by Amazone Ltd based on the examined voice of consumers.

\section{Research results and discussion}

An aggregation of data on the number of farms in Latvia that are engaged in grain production reveals that the number of farms tended to decrease, whereas the total area cropped with grains increased (Figure 1). 


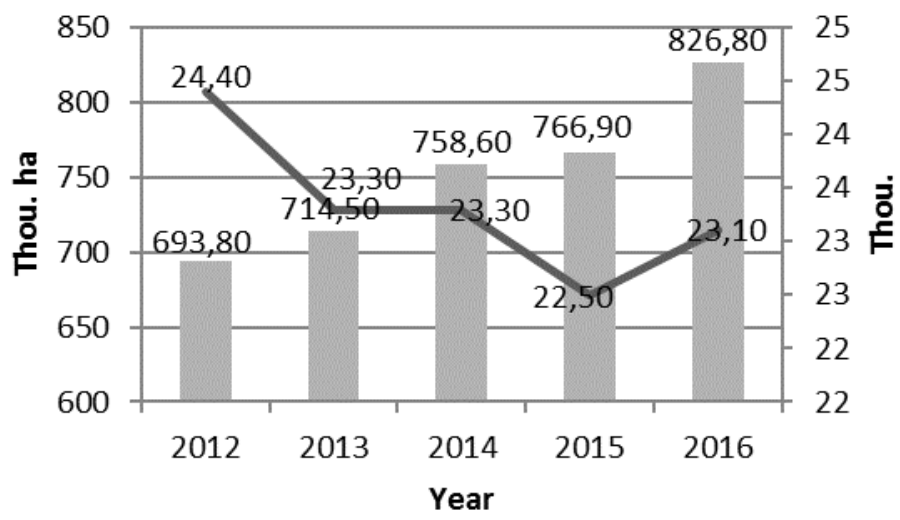

Cropped area, thou. Ha

Number of farms, thou

Source: authors' construction based on Latvijas statistikas..., 2017

Fig. 1. Number of grain farms and the cropped area in Latvia in the period 2012-2016

This trend could be explained by the fact that small grain farms could not survive and changed their field of economic activity. In the result, large farms bought more agricultural land and made their position in the market stronger.

Grain farming is not homogenously developed in the entire territory of the country (Figures 2 and 3).

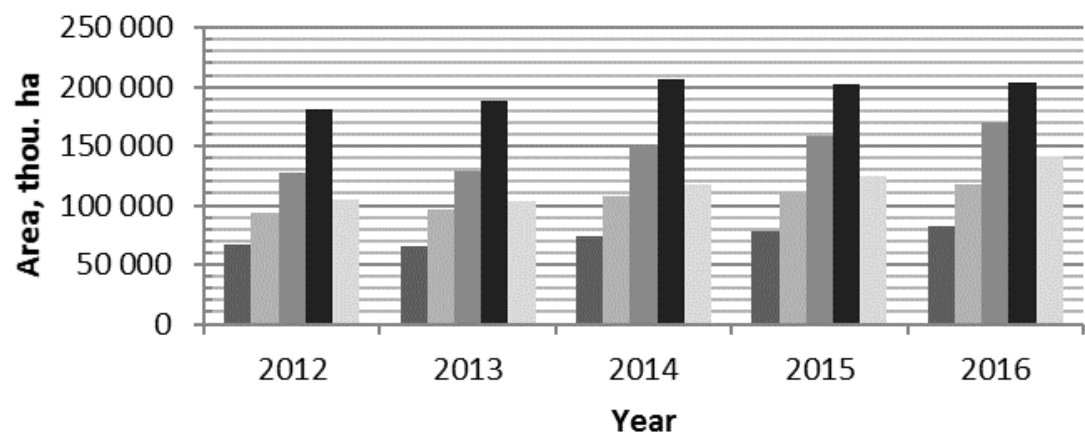

- Pierīgas region

Vidzemes region

Kurzemes region

Zemgales region

Latgales region

Source: authors' construction based on Latvijas statistikas..., 2017

Fig. 2. Grain area in the regions of Latvia in the period 2012-2016, thou. ha

An analysis of the data of Figure 2 reveals that the smallest grain areas were reported in the regions of Pieriga and Vidzeme. Pieriga is densely populated (population density - 36 people per $\mathrm{km}^{2}$, while the national average was 30 people per $\mathrm{km}^{2}$ ), hence opportunities to use land for agricultural production are limited, while Vidzeme region has a hilly terrain that makes land tillage difficult; besides, the land is less fertile. The largest area under grains is reported in Zemgale region, which could be explained by very fertile agricultural land, an appropriate terrain for land tillage as well as more favourable climatic conditions for farming.

As shown in Figure 3, the smallest grain output was reported in Pieriga region as well as in Latgale region that has a hilly terrain. The output of grain in the regions of Vidzeme and Kurzeme was quite large, yet the largest grain output was reported in Zemgale region because the region has fertile soils, a flat terrain and a well-developed agricultural sector, the grain industry in particular. 


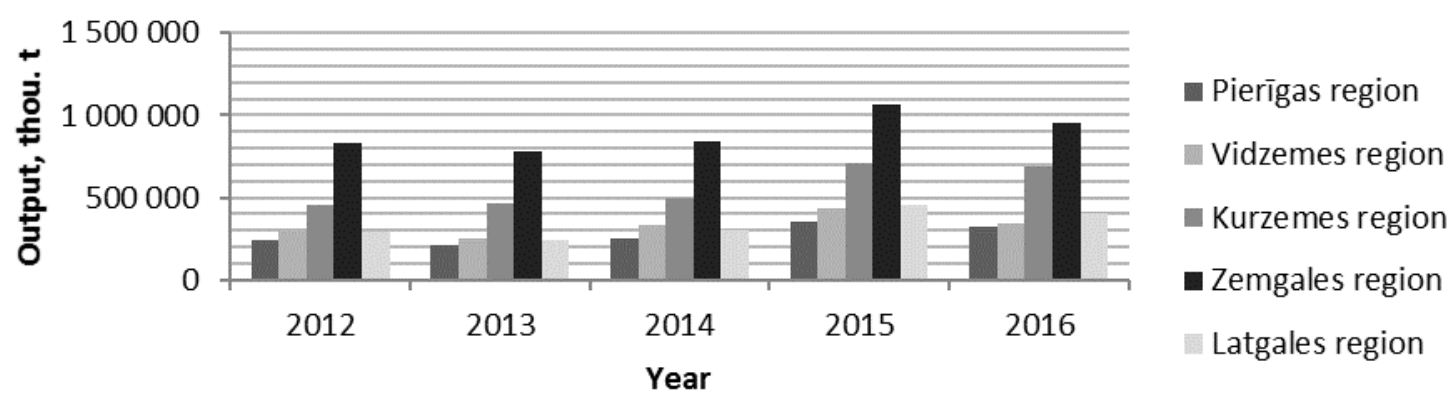

Source: authors' construction based on Latvijas statistikas..., 2017

Fig. 3. Grain output in the regions of Latvia in the period 2012-2016, thou. $t$

\section{Trends in the development of the industry of cereals, legumes and industrial crops}

The output of grain considerably increased in 2004 when Latvia joined the EU. In 2015, the area cropped with grains approached the historically highest level that was reached in the early 1990s. The successful development of the grain industry was due to a number of factors: direct and indirect EU financial support for farmers, attractive grain prices, easy access to the EU market and consolidation processes in the agricultural sector that involved production intensification and the use of the latest technologies.

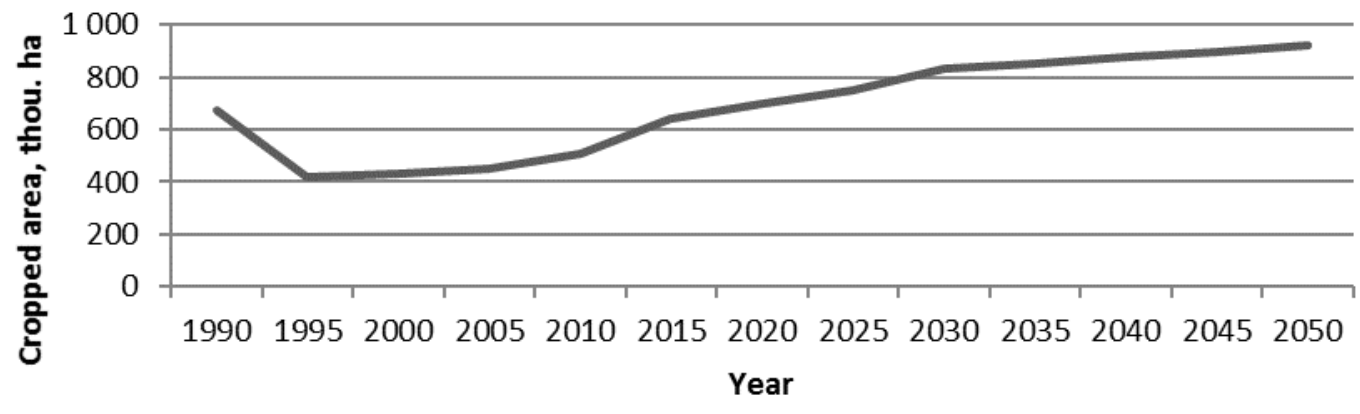

Source: authors' construction based on Latvijas attistibas..., 2017

Fig. 4. Grain area and a projection of the area in Latvia for the period 1990-2050, thou. ha

As shown in Figure 4, in the period 1990-2015 the area cropped with grains varied, reaching 716.0 thou. ha in 2016. By 2050 compared with 2030, the area is projected to increase by $37 \%$ to 918.4 thou. ha; compared with 2015, the area is projected to increase by $23 \%$ to 829.1 thou. ha. In the opinion of the authors, a projection through to 2030 is more reliable, as it represents a shorter period and the situation in $\mathbf{2 0 3 0}$ might not be much different from the current situation.

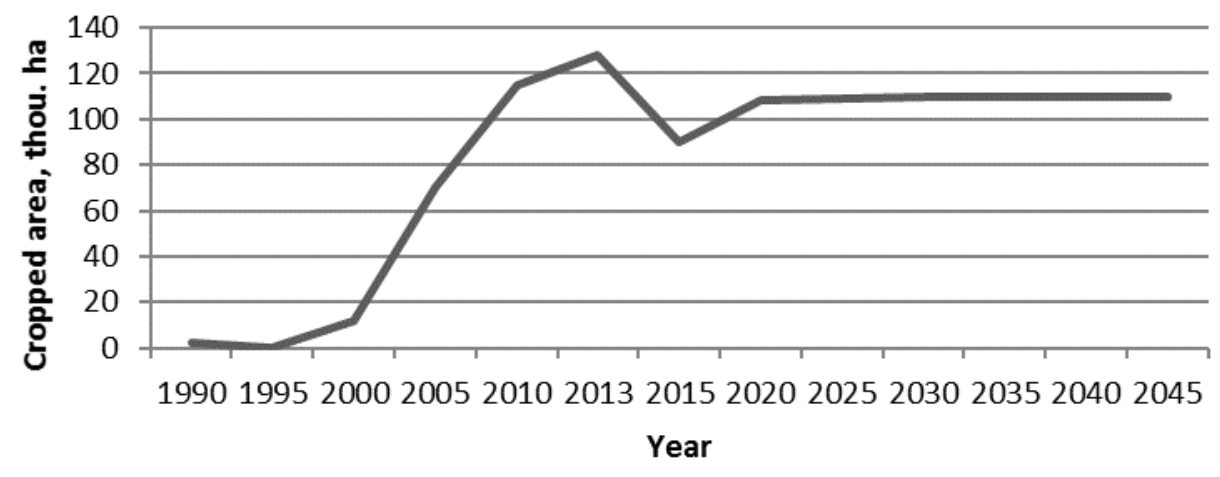

Source: authors' construction based on Latvijas attistibas...,2017

Fig. 5. Rapeseed area and a projection of the area in Latvia for the period 1990-2050, thou. ha 
As shown in Figure 5, rapeseed production began from zero in the middle of the 1990s; in 2013 the rapeseed area reached 128 thou. ha, while in 2015 it decreased to 89 thou. ha. In 2016 compared with 2015 , the rapeseed area increased by $13.6 \%$ (to 101 thou. ha). It is projected that the rapeseed area might increase to 113.3 thou. ha by 2050, which is $27 \%$ more than in 2015 .

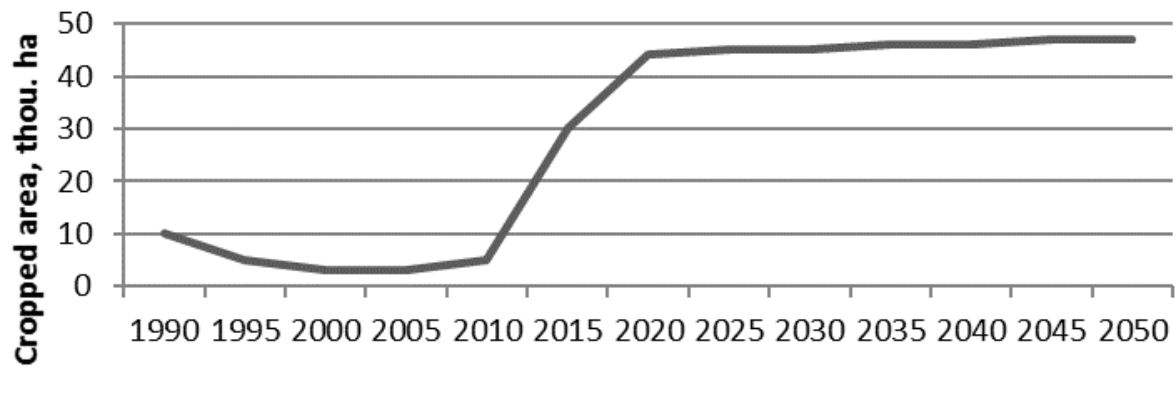

Year

Source: authors' construction based on Latvijas attistibas..., 2017

Fig. 6. Area cropped with legumes and a projection of the area in Latvia for the period 1990-2050, thou. ha

The area under legumes considerably increased owing to agricultural policy stimuli, which are part of the greening programme. At present, legumes occupy $3.5 \%$ of the total cropped arable land area. As shown in Figure 6, the largest increase is projected in the period through to 2020, while in the period until 2050 an increase might be minimal. Compared with 2015 when the area under legumes was 31.6 thou. ha, the area is projected to increase by $51 \%$ to 47.6 thou. ha by 2050 .

Table 1.

Projection of crop yields in Latvia for the period 2015-2050

\begin{tabular}{|l|c|c|c|c|c|c|c|c|c|}
\hline \multirow{2}{*}{ Crop } & \multirow{2}{*}{$\mathbf{2 0 1 5}$} & \multicolumn{6}{|c|}{ Projection of crop yields, t*ha-1 } & $\begin{array}{c}\text { Increase } \\
\text { from the } \\
\text { base } \\
\text { year, \% }\end{array}$ \\
\cline { 3 - 11 } & & $\mathbf{2 0 2 0}$ & $\mathbf{2 0 2 5}$ & $\mathbf{2 0 3 0}$ & $\mathbf{2 0 3 5}$ & $\mathbf{2 0 4 0}$ & $\mathbf{2 0 4 5}$ & $\mathbf{2 0 5 0}$ & $\begin{array}{c}\text { \% } \\
\text { Wheat }\end{array}$ \\
\hline Barley & 2.5 & 4.4 & 4.7 & 5.3 & 5.5 & 5.9 & 6.4 & 7 & 75 \\
\hline Rye & 2.5 & 2.7 & 2.9 & 3.1 & 3.3 & 3.5 & 3.7 & 4 & 60 \\
\hline Oats & 2 & 2.1 & 2.2 & 2.4 & 2.6 & 2.7 & 2.8 & 3 & 50 \\
\hline Pulses & 2.2 & 2.5 & 2.7 & 3 & 3.3 & 3.5 & 3.8 & 4 & 82 \\
\hline Rapeseed & 2.3 & 2.6 & 2.8 & 3.1 & 3.3 & 3.5 & 3.8 & 4 & 74 \\
\hline
\end{tabular}

Source: authors' construction based on Latvijas attistibas..., 2017

According to some experts, crop yields will tend to increase in the period through to 2050. It might be due to the use of new crop varieties that both provide higher yields and withstand unpredictable weather conditions. The largest increase in absolute terms is projected for wheat: from 4 t/ha in 2015 to 7 t/ha by 2050, while in relative terms it might be for legumes with an $82 \%$ increase in the yield.

In the period 2005-2016, grain prices in the EU were very volatile, reaching the maximum price in 2012 and fluctuating in the range of 220-240 EUR/t, while the lowest price was in 2009, reaching 105-130 EUR/t. This could be explained by the global crisis. However, the prices have gradually recovered year by year. The prices have been in the range from 180 to $190 \mathrm{EUR} / \mathrm{t}$ up to 2017. In a long-term, the prices might stabilise at approximately $180 \mathrm{EUR} / \mathrm{t}$.

Harvesting grain by agricultural machinery (grain harvesters), the grain could contain various impurities: chaff, weed seeds, other kinds of grain, damaged grains and inorganic substances. 
Grain is used as food, feed as well as a raw material for industry; therefore, the grain has to be cleaned off the mentioned impurities. The second problem is grain moisture, which often exceeds the level to be stored for a long period. For both reasons, grain (seed) has to be pre-processed the grain is cleaned off any impurities, sorted and dried - to be stored or processed further.

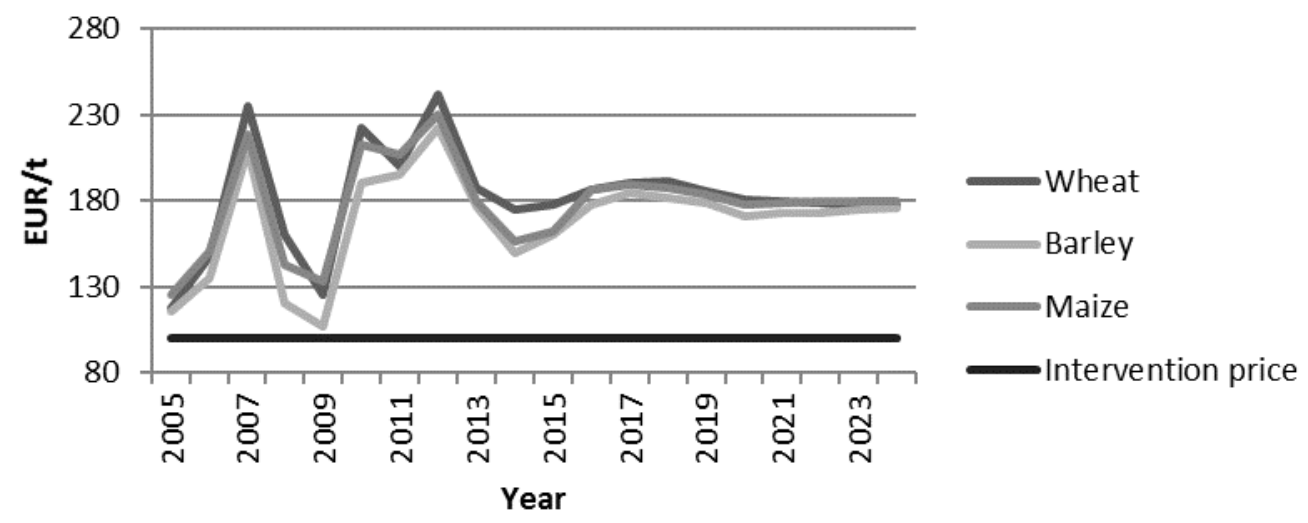

Source: authors' construction based on Pilvere...,2016

Fig. 7. Grain prices in the European Union in the period 2005-2024, EUR/t

The situation and projections indicate that the grain industry could continue growing in Latvia, thereby increasing the demand for construction of grain pre-processing complexes. For this reason, it is important to identify the needs of potential customers (consumer voices) that affect the demand.

The research interviewed representatives of four farms (Vidini MS Ltd, Ansites, Upeskalni AB Ltd and Raucini Ltd). It was a partly structured interview with 11 questions, which aimed at identifying whether the construction of new grain pre-processing complexes is sufficiently efficient and the investment pays off.

The key crop that is pre-processed at such complexes is winter wheat; according to statistics too, it is a crop that is pre-processed in the largest quantities. Winter rapeseed and winter barley are dried at complexes in smaller quantities, followed by spring grains (barley, wheat, oats and rapeseed). This means that service providers, before advising a potential customer on the construction of a grain pre-processing complex, have to stress that the equipment is tailored particularly for crops grown in Latvia. Service providers have to supply a technology to a customer that is ideally suited for climatic conditions in Latvia and typical crops.

As regards grain pre-processing and storage, the research found out that most of the farms did grain pre-processing already before the construction of a complex, transporting all their harvested crop from fields to a pre-processing facility, as most farms were not able to purchase and maintain grain pre-processing complexes in Latvia in the late 1990s.

The opinions of the interviewees on grain drying capacity and quantities slightly differed, yet each of them admitted that if using the latest technologies, costs are considerably lower - up to twofold. The research identified that each farm could dry and store a sufficient quantity of grain, yet they gradually faced the need to enhance their grain pre-processing complexes. It confirms one more time that the demand for this service is going to increase in future.

It is important to identify whether it is necessary to construct a grain pre-processing complex. Each farm admitted that costs are considerably lower if drying grain themselves at their facility instead of taking the grain to another grain pre-processor or to a seaport. A slightly different 
opinion was expressed by Raucini Ltd that did not intend to reconstruct its pre-processing complex because its capacity and the quality of their grain for feed and seed were completely sufficient.

The interviews revealed that the key criteria for a grain pre-processing complex were storage and processing capacity. Of course, the quality of equipment was essential in order not to make additional investments in the equipment after a few seasons. The farm representatives revealed that they chose a producer that their neighbours or acquaintances cooperated with, as it gave them an opportunity to see and question about the particular solution. This means that person-to-person advertising is important for the promotion of this service in the market.

It was also important to find out what was a better option for the farms - to use their existing grain pre-processing complexes, to take the grain to another grain pre-processor or to construct a new complex. The results were surprising, as the cost for each farm would decrease by half if using the newest solutions. By using the newest technologies, it is possible to save a lot because there is no need for doing repairs and it is easy to control the pre-processing process. This allows doing grain pre-processing at high quality and gives an opportunity to expand farm business.

The construction of a grain pre-processing complex is quite a large investment; therefore, farms prefer submitting a project proposal to get EU financial support.

The opinions of the farms about providing pre-processing services to other farms were different, and most of them believed that it was not profitable to do it because they had a sufficient quantity of their own grain to be processed. Nevertheless, Upeskalni AB Ltd planned to serve some customers because their grain dryer operated at half capacity if pre-processing only their own grain, thereby making the investment payoff period longer.

The farms used various technological solutions, yet the most popular one was continuous flow dryers that ensured the highest efficacy factor, according to their technical characteristics. Farms usually choose a pre-processing capacity that is sufficient for their current grain production quantities, yet experience shows that a better idea is to construct a complex that has some extra capacity. The most popular source of energy for drying grain is natural gas, which ensures the highest thermal capacity, lower maintenance costs and occupies a smaller area.

Grain pre-processing always involves some shortcomings and imperfections. The interviews revealed that the largest shortcomings were as follows: necessity for extra storage containers, corrections needed in technological solutions and the control system with pre-set options for grain quality. The grain dryers of the farms have been constructed with no overhangs, yet an overhang would be necessary in case precipitation can reach the moving systems of equipment, even though the equipment is hermetic.

Based on the findings made in the research, a quality function deployment matrix was constructed for pre-processing services provided by Amazone Ltd (Figure 8).

Amazone Ltd is located in Kurzeme region and was founded in 1993 as an official representative of the German company Amazonen-Werke in Latvia.

Amazone Ltd supplies various agricultural machinery and is an official importer in Latvia for the following foreign companies: Amazone, Krone, Grimme, Annaburger, Tanco, Lechler, Fortuna and Walterscheid. It also supplies soil tillage equipment, feed preparation equipment, potato planting and harvesting equipment, power-take-off shafts, suspension systems and sprayer nozzles. Amazone Ltd also represents Mepu, a company which supplies grain dryers, and Ducker, a producer of specific machinery. 


\section{Amazone Ltd serves about 1000 farms throughout Latvia.}

Amazone Ltd supplies the following high-quality grain pre-processing equipment produced by Mepu in Finland, a company with 60-year experience in the grain industry: grain dryers, grain towers and grain conveyers. It also persistently conducts studies and develops its products, following the newest innovations and supplying modern technological solutions to customers.

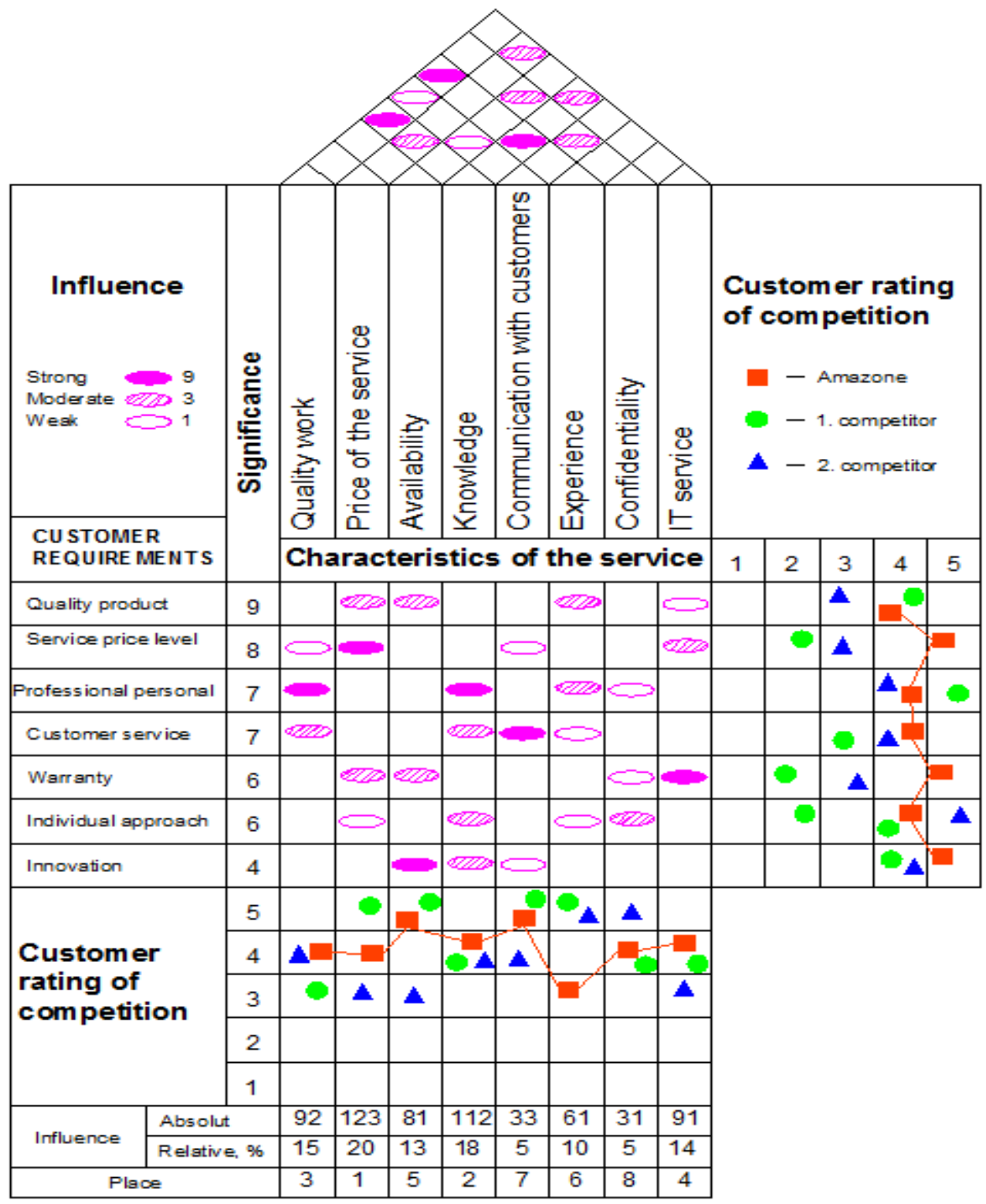

Source: authors' construction

Fig. 8 Quality function deployment (QFD) matrix for grain pre-processing services provided by Amazone Ltd

QFD is a technique employed to develop a product based on customer wishes. Two competitors: Competitor 1 (Voka Ltd) and Competitor 2 (Graintech Ltd), which were larger in terms of the number of employees and customers than Amazone Ltd, were evaluated using a QFD matric.

The most essential criteria, based on which service prices are set for the customers of Amazone Ltd, are as follows:

- individual approach;

- high quality product;

- professional personnel;

- establishment of long-term relations. 
The customer ratings of Amazone Ltd revealed that the customers consider Amazone Ltd a new company providing grain pre-processing services, yet it is a strong competitor because has operated in the agricultural industry for more than two decades, supplying quality products, providing equipment maintenance services and guaranteeing the operation of grain dryers. Unlike the competitors, the prices of services of Amazone Ltd are relatively high, thereby presenting itself in the grain pre-processing market as a stable, development-oriented company.

\section{Conclusions, proposals, recommendations}

1) In the period 2012-2016 in Latvia, the number of grain farms decreased, while the area cropped with grains increased, and the area is going to continue increasing in the future. The largest grain harvest and the largest area under grains is reported in the fertile and flat region of Zemgale.

2) The key customer requirements (voice of the consumer) for a grain pre-processing complex is (1) technologies appropriate for the climatic conditions and crops grown in Latvia, (2) adequate equipment capacity for pre-processing and storage, (3) adequate equipment quality and technologies necessary for customers.

3) Farms that are engaged in grain pre-processing reveal that the construction of a new complex or the reconstruction of the existing one reduce processing costs up to two-fold and ensure a high efficiency factor of the equipment.

4) The key characteristics of services provided by a potential grain pre-processing complex of Amazone Ltd have to be as follows: reasonable price, an advanced employee knowledge and high-quality services.

5) To contribute to the development of grain pre-processing complexes in future too, support of the Ministry of Agriculture is necessary, as the Agricultural Development Programme is available to farmers only until 2020. It is necessary to establish an additional national support fund for agricultural enterprises that are engaged in pre-processing.

\section{Bibliography}

1. Balodis O. (2016) Graudkopibas nozares apskats par 2016.gadu (Grain Farming Industry Overview for 2016) Retrieved :http://new.Ilkc.lv/sites/default/files/baskik_p/pielikumi/graudkopiba.pdf Access: 07.10.2017.

2. Central Statistical Bureau of Latvia. (2017). Area, Population Density and Resident Population by Statistical Region, City and County.

Retrieved: http://data.csb.gov.Iv/pxweb/en/Sociala/Sociala_ikgad_iedz_iedzskaits/IS0010.px/?rxid=cdc b978c-22b0-416a-aacc-aa650d3e2ce0

3. Latvijas lauksaimnieciba 2017 (Latvian Agriculture 2017) (2017). ZM lauksaimniecibas gada zinojums par 2016. gadu (Agriculture Annual Report 2017), 46.p.

Retrieved: https://www.zm.gov.Iv/public/files/CMS_Static_Page_Doc/00/00/01/10/04/fs01usersLinda.BirinaDesktopAA2017_lauksaimniecibasgadazinojums.pdf Access: 07.10.2017.

4. Lauksaimniecibas attistibas prognozesana un politikas scenariju izstrade lidz 2050. gadam (Forecasting Agricultural Development and Developing Policy Scenarios up to 2050) (2016) pp. 77-78

Retrieved: https://www.zm.gov.Iv/public/ck/files/Lauksaimniecibas \%20attistibas \%20prognozes \%202050. pdf Access: 08.10.2017.

5. Pilvere I. (2016) Latvijas attistibas prognozesana un politikas scenariju izstrade līdz 2050. gadam (Prognosis of Latvia's Development and Development of Policy Scenarios up to 2050) [tiessaiste]

Retrieved: http://www.Ilka.Iv/f/latvijas_graudu_nozares_attistibas_tendences_rigonda_krievina_22102015. pdf. Access: 10.10.2017. 